\title{
Tranmission of a Global Financial Crisis Shock to an Emerging Economy
}

\author{
Asim Rehman ${ }^{1}$, Sajid M. Chaudhry ${ }^{2}$ and Syed Mujahid \\ Hussain $^{3}$
}

\begin{abstract}
Using a unique dataset consisting of all corporate loans in Pakistan, we study the impact of the global financial crisis (GFC) on the lending ability of its banking sector. We also take into account various bank and loan types along with extensive margins, firm size effects and impact of information asymmetry. Our findings show that the Pakistani banking sector was indeed affected by the GFC as high exposure banks, who borrow relatively more internationally, reduce lending to local firms and this impact is larger for small firms. We also find differences in the lending ability of various bank types and loan types. By using direct information asymmetry measure, we find that banks reduced lending after the financial shock. However, the information gathered from the previous relationship of the borrower with relatively low exposure banks can overcome the negative financial shock and increase lending after the shock. These findings are very relevant in the context of the spillover effects of the GFC and have important policy implications for emerging markets.
\end{abstract}

Keywords: Financial Contagion, Financial Crisis, Banks, Information Asymmetry JEL Codes: G01, G21, D82

\footnotetext{
${ }^{1}$ National University of Sciences and Technology, Islamabad, Pakistan. Email: asim.rehman@nbs.nust.edu.pk; ${ }^{2}$ (Corresponding author) Economics, Finance and Entrepreneurship Group, Aston Business School, Aston University, Birmingham, B4 7ET, United Kingdom. Email: s.m.chaudhry@outlook.com, ${ }^{3}$ Department of Economics and Finance, College of Economics and Political Science, Sultan Qaboos University, Muscat, Oman. Email: smujahid@squ.edu.om. We are extremely grateful to the State Bank of Pakistan (SBP) for providing the data used in this paper. We also would like to thank the editor and two anonymous reviewers for their very helpful suggestions and remarks. We thank the participants of the Portsmouth-Fordham Conference on Banking and Finance 2016 and the $4^{\text {th }}$ European Conference on Banking and the Economy (ECOBATE 2016).
} 


\section{Introduction}

Banks around the world are interconnected because they provide lending and other financial services, not only to domestic financial and non-financial firms, but also to customers abroad. On one hand, this interconnection provides liquidity support and reduces the idiosyncratic risk of individual banks via diversification, while on the other hand it also leaves banks vulnerable to systemic shock in the form of a speculative attack, financial panic, or herd behavior (Kleimeier et al., 2008). An important question is whether, and to what extent, this systemic shock is transmitted to the real economy. ${ }^{1}$ In this regard, the impact of the last global financial crisis (GFC) of 2007-09 on real businesses has also attracted considerable attention (see Ivashina and Scharfstein, 2010; Giannetti and Laeven, 2012; Schnabl, 2012; de Haas and van Horen, 2013; Berg and Kirschenmann, 2015). However, the impact of the GFC on emerging markets has been the subject of relatively few studies, probably due to the limited availability of data. $^{2}$

As we had access to the relevant data, we study the impact of the GFC on an emerging market. In doing so, we analyze the changes in credit availability to firms in Pakistan as a result of the exogenous economic shock, measured as borrowing outside Pakistan by Pakistani banks. ${ }^{3}$ Since the banks and financial intermediaries in developed countries were directly and most severely affected during the GFC, we examine whether transmission of capital flows from international banks to local banks in an emerging economy was also affected by the liquidity constraints faced by the international banks (Khwaja and Mian, 2008; Cetorelli and Goldberg, 2012). Pakistan had close trading relationship with the countries from where the GFC originated. Based on 2006 data, United States was the biggest trading partner of Pakistan. Moreover, six European countries were also among the top ten trading partners of Pakistan. ${ }^{4}$ We reckon that the countries with significant trading relationship with Pakistan were also closely linked to the Pakistani banking sector. Therefore, the main objective of this paper is to study whether the financial shock that originated in those countries impacted the Pakistani economy during the GFC through the credit channel. To that end, we use a unique dataset

\footnotetext{
${ }^{1}$ There is extensive literature which studies the impact of financial shocks on the real economy (see Bernanke, 1983 and Bernanke and Blinder, 1988, 1992 for early examples). See also BIS (2011) for a survey of the linkages between the financial and real sectors.

${ }^{2}$ Among the few papers that have addressed this issue in emerging markets, Paravisini et al. (2015) study credit shock to exporting firms in Peru, and Berg \& Kirschenmann (2015) study the impact of GFC on the agriculture sector in Azerbaijan.

${ }^{3}$ We also use advances outside Pakistan as a percentage of total bank advances as a proxy for calculating international exposure to establish if the shock was a general financial one.

${ }^{4}$ Appendix Table 1 shows the trading links with top twelve countries in the world.
} 
obtained from the Credit Information Bureau (CIB) of the State Bank of Pakistan, comprising all business loans made to firms by commercial banks in Pakistan, to estimate the transmission of the economic shock via spillover from banks to real firms.

In order to establish the adverse effects of international shocks through the banking system, the Pakistani banking sector provides an ideal setting to study the transmission of international financial shocks, as local banks differ greatly in their international exposure. The international exposure of these banks ranges from zero to $22.3 \%$. We measure this international exposure by the borrowing of Pakistani banks outside Pakistan from other financial institutions, and hypothesize that the higher the borrowing outside Pakistan, the higher the financial shock to banks, and hence those banks transmit the shock to the real economy in Pakistan. Our primary variables of interest are high, intermediate and low exposure banks, classified as follows. Banks which have over $8 \%$ of their total borrowing outside Pakistan are considered as high exposure ones, while those with between $4 \%$ to $8 \%$ borrowing outside Pakistan are classified as intermediate exposure banks, and those with less than $4 \%$ borrowing outside Pakistan as low exposure banks. ${ }^{5}$ The higher the exposure of the banks, the more they are expected to transmit the financial shock to the local market. ${ }^{6}$ This classification is similar to that of Schnabl (2012), who classifies banks into these categories and then measures the impact of lending changes by each type of bank on firms in Peru. The uniqueness of our dataset lies in the fact that it covers the period of the GFC perfectly, i.e., from April 2006 to March 2011. It contains all the business loans that were outstanding at the month-end with each bank, which allows us to address the identification challenge arising from the economic events that triggered the financial shocks. These shocks may also affect credit demand.

Our findings show that the banking sector in Pakistan was indeed affected by the GFC, as the lending ability of various banks was negatively affected (i.e., the intensive margin), similar to the findings of Forbes (2001), Forbes and Chinn (2004), Khwaja and Mian (2008), Schnabl (2012) and Cetorelli and Goldberg (2012). Our empirical results also indicate that there was transmission of financial shock from international markets to Pakistan. This finding is

\footnotetext{
${ }^{5}$ We have also examined the sensitivity of our results to different exposure thresholds by changing thresholds to over 6\% (high exposure banks), 3-6\% (intermediate exposure banks) and below 3\% (low exposure banks) and to over $9 \%$ (high exposure banks), 5-9\% (intermediate exposure banks) and below 5\% (low exposure banks). Our results are robust to changes in these thresholds and are available upon request from authors.

${ }^{6}$ As discussed above, we also use advances outside Pakistan as a percentage of total bank advances as a proxy for calculating international exposure. The higher the exposure outside Pakistan, the greater the chances of transmission of shock from outside to domestic Pakistani banks. This definition of transmission is similar to international financial contagion. Most of the results are robust to this definition of high, intermediate and low exposure.
} 
interesting because Ali (2009) notes that Pakistan has been relatively well-insulated against contagion coming from international financial markets. ${ }^{7}$ Our results, however, confirm that lending by Pakistani banks to local firms was reduced. This reduction in lending was reported by the high exposure banks, while there was increase in lending by the low/relatively low ${ }^{8}$ exposure banks. We also find that "foreign" banks ${ }^{9}$ transmit the global financial crisis shock and reduce their lending. The findings on the exit from the market of old firms and the extension of credit to new firms (i.e., the extensive margin) indicate that the firms which borrowd from relatively low exposure banks are less likely to exit and are more likely to have survived after the crisis. However, lending to small firms was reduced, irrespective of whether they borrowed from relatively low or high exposure banks. The findings regarding different types of banks reveal that private and big banks reduce their lending; however, contrary to Farooq and Zaheer (2015), we do not find any statistically significant evidence that the granting of Islamic loans increased after the financial shock. We find that high exposure banks reduced their agricultural loans after the financial shock in contrast with Berg and Kirschenmann (2015). However, relatively low exposure banks increased their lending in that regard. This is intuitive, because the relatively low exposure banks are mostly domestic, small banks, which mainly focus on agriculture financing. Our findings on information asymmetry show that bank reputation as a proxy for information asymmetry, as well as the previous interaction of the borrower with the bank, were not able to overcome the information asymmetry problems and banks still reduced lending after a financial shock. However, highly reputed banks with relatively low exposure were able to overcome the information asymmetry problems and increased their lending after the GFC.

Our paper adds to the existing literature in the following ways. First, it complements the rare literature on the transmission of the global financial crisis from developed countries to banks and firms in an emerging economy. Second, we provide a detailed analysis of different bank types (e.g., private and privatized banks ${ }^{10}$ ) and different types of loans (e.g., Islamic, export

\footnotetext{
${ }^{7}$ Dungey and Gajurel (2015), however, in a mutli-country study, show that Pakistani banking sector experienced systemic and idiosyncratic contagion during the global financial crisis.

${ }^{8}$ From Table 4 onward, we combine the intermediate exposure and low exposure bank proxies, and use the term 'relatively low' exposure banks. Therefore, banks with $8 \%$ or less international exposures are classified as relatively low exposure banks.

9 "Foreign" banks are those banks, a treatment group, who have international borrowing compared to the banks which do not have any international borrowing at all, a control group.

${ }^{10}$ Four large government owned banks in Pakistan were privatized in the massive wave of banking sector privatization during the 1990s. Because of this, they are classified as 'privatized' in our database, and we continue using this term throughout this paper. This 'privatized' proxy should also be considered as a proxy for large banks, because they have about $41 \%$ of the market share.
} 
and agriculture loans) provided by local banks. By doing this, we are better able to analyze the impact of the global financial crisis on the real economy in Pakistan. Third, our analysis also sheds light on information asymmetry and its impact on lending changes after the recent financial crisis using loan level data. Lastly, our dataset perfectly covers the relevant data period, i.e., from April 2006 to March 2011, giving us the possibility to conduct the analysis for both pre-crisis and post-crisis periods. ${ }^{11}$

The remainder of the paper is structured as follows. Section 2 provides the study background, while Section 3 describes the data. The methodology adopted in the paper is described in section 4. Section 5 presents the results and the conclusion is provided in section 6 .

\section{Theoretical background and related literature}

Our paper is related to two strands of literature. The first is the literature on the transmission of financial shocks, which operates through various channels. Next to the asset price channel ${ }^{12}$ of transmission, the credit channel operates through information asymmetry in financial markets. ${ }^{13}$ This channel proposes two types of transmission: the bank lending channel and firms' borrowing channel. According to the bank lending channel, banks play an important role in solving the asymmetric information problem; certain borrowers will not be able to have access to credit in the presence of a financial shock to banks. Existing work on the bank lending channel includes Kashyap et al. (1994), Peek and Rosengren (1997), Kashyap and Stein (2000), Ashcraft (2001), Khwaja and Mian (2008) and Cetorreli and Goldberg (2012). The firm borrowing channel implies that when a financial shock reduces the net worth of firms, it raises the adverse selection problem, leading to a decreased lending to firms. A decline in net worth also increases the moral hazard problem because firms have lower equity at stake and are more likely to engage in risky investment projects. Lenders can observe this and reduce lending to firms (Oliner and Rudebusch, 1996; Bernanke et al., 1996). Other papers have analyzed the transmission channels of international financial shocks through the banking system. Allen (2012) showed that bank liquidity shocks are transmitted from the parent to the subsidiary,

\footnotetext{
${ }^{11}$ Earlier papers using the same data included the period 1996-2001/2 (Khwaja and Mian, 2005, 2008; Mian, 2006; Zia, 2008) and April 2006 to December 2008 (Baele et al., 2014).

12 See Taylor (1995) and Bernanke and Gertler (1995) for the interest rate channel, Bryant et al. (1993) and Macdonald and Taylor (1993) for the exchange rate channel, and Modigiliani (1975) for the wealth effects of transmission.

${ }^{13}$ See Bernanke (1993), Bernanke and Gertler (1995), Cecchetti (1995) and Hubbard (1995) for the credit channel.
} 
thereby negatively affecting lending by the subsidiaries. Similarly, Kane et al. (2015) studied the channels which affect credit provision during a financial crisis. Their results indicate that cross-border lending was affected, mainly due to liquidity difficulties faced by international banks and increased uncertainty.

The second strand of literature which our paper relates to is international financial contagion. The literature on this strand can be divided into studies focusing on financial sector linkages for the propagation of economic shock (Forbes and Rigobon, 2002; Corsetti et al., 2005; Bekaert et al., 2005; Derviz and Podpiera, 2007; Jokashthira et al., 2013), and others which focus on trade linkages (Eichengreen et al., 1996; Forbes, 2001, 2004; Claessens and Forbes, 2001; Forbes and Chinn, 2004; Blanchard et al., 2010). Forbes (2001) describes three channels through which an economic shock can be transmitted to other countries: a competitiveness effect, which has a negative effect on exports because of the adverse impact on relative competitiveness; an income effect, which also has a negative effect because of the adverse impact on income in the importing country and hence a reduction in demand for imports; and a cheap import effect, which has a positive effect because of the positive impact on relative competitiveness, and hence an increase in demand for imports. This paper complements the research on the international transmission of financial shocks and international financial contagion.

Overall, our study relates closely to work by Khwaja and Mian (2008), Schnabl (2012) and Cetorelli and Goldberg (2010). Khwaja and Mian (2008) and Schnabl (2012) study the transmission of liquidity shock to real firms by using firm fixed effects to identify the bank lending channel. These studies, however, differ from ours, as that of Khwaja and Mian (2008) analyzes the transmission of domestic liquidity, whereas Schnabl (2012) studies the transmission of liquidity shock across countries. We discuss the spillover of financial shock from the developed world to an emerging economy during the global financial crisis, and subsequently the transmission of that financial shock to real firms by local banks. Our paper is also different from that of Cetorelli and Goldberg (2010) in the sense that they analyze the financial contagion from banking systems in developed countries to emerging markets, using data on capital flows within global banks, while we study the transmission of financial shock from developed banking systems to an emerging market using loan level data.

\section{Data}


We use a unique dataset for our empirical analysis which primarily consists of loans provided by Pakistani banks to local firms. The data were obtained from the Consumer Protection Department of the State Bank of Pakistan, which maintains the domestic credit registry known as the Credit Information Bureau (CIB). CIB is an online facility that allows financial institutions to upload and retrieve information through a virtual private network. Since 2006, the State Bank of Pakistan has upgraded the CIB's technical and reporting structure. The new facility has the capacity to incorporate a large number of validation rules to ensure the integrity and accuracy of the submitted data. Banks in Pakistan verify the credit history of a loan applicant with CIB if the application exceeds PKR 500,000. The CIB dataset has already been studied in different contexts by Khwaja and Mian (2005, 2008), Mian (2006), Zia (2008) and Baele et al. (2014). ${ }^{14}$ Our data cover the period from April 2006 to March 2011, spanning the period before and after the financial crisis of 2007-2009.

The CIB reports the identity code for each loan contract. Based on this, we can identify the industry and total exposure of the borrower. In addition, the database provides information on key loan characteristics, such as maturity, collateral, product name, type of loan, the approved limit and the remaining outstanding amount. Because the database does not provide banks' financial information, data on bank characteristics such as total capital ratio, total assets, liquid assets and the number of branches of each bank were obtained from Bankscope.

As we are studying the impact of the financial crisis on the changes in lending ability of the Pakistani banking sector, we divided our data into three samples: pre-crisis, crisis and postcrisis. The pre-crisis period includes data from April 2006 to June 2007; the crisis period ranges from July 2007 to March 2009; and post-crisis is from April 2009 to March 2011. We follow Dungey and Gajurel (2015) in defining the crisis period. They use July 2007 to March 2009 as a crisis period and find that Pakistani banking sector experienced systematic contagion as well as idiosyncratic contagion during the global financial crisis. ${ }^{15}$

Because we are interested in the changes in lending before and after the crisis, we start with 100,938 loan observations from 23,188 borrowers. ${ }^{16}$ We discard all loans given by any other

\footnotetext{
${ }^{14}$ Because of the technical and reporting structure upgrade, the quality of the data has further improved since 2006.

${ }^{15}$ We also use NBER US recessions to define the crisis period from January 2008 to July 2009. The recession period in the US was from December 2007 to June 2009 (http://www.nber.org/cycles.html). Except for Export and Islamic loans, our results are not sensitive to a slightly different definition of the crisis period (January 2008 to July 2009).

${ }^{16}$ Our original dataset included almost 6 million loan-month observations during the 59-month sample period (April 2006 to March 2011)
} 
financial institution except twenty one commercial banks, which gives us 71,621 observations. We also discard loans given as a non-funded facility, which then leaves us with 59,183 observations. Some of our analysis contains all these observations. However, because of the firm fixed effects approach, we filter out the borrowers who borrowed only from one bank and include only those firms which borrowed from more than one bank prior to the crisis. In the next step, we consolidate the borrowing portfolios of all borrowers corresponding to the respective lenders, controlling for the various financial products under consideration. ${ }^{17}$ This gives us 33,245 observations; most of our analysis is made on this number of observations, from 11,524 borrowers.

The filtered dataset includes a total of twenty one banking institutions in Pakistan. These include eight private, four privatized, two provincial and two nationalized banks, two foreign and three Islamic banks operating in Pakistan. Our dependent variable is the change in loan $\mathrm{i}$ of firm $\mathrm{j}$ from bank $\mathrm{b}\left(\Delta \mathbf{L}_{\mathrm{ijb}}\right)$. We transform all the loan values to logarithmic form and obtain the difference between the logarithmic values of lending by banks prior to and after the shock, such that a positive value indicates that there has been an increase in lending post financial crisis, and a negative value indicates that lending has decreased following the GFC. Our primary variables of interest are high, intermediate and low exposure banks. As explained above, we classify these as follows: banks which have over $8 \%$ of their borrowing from outside Pakistan are considered as high exposure and those with between $4 \%$ to $8 \%$ and less than $4 \%$ borrowing from outside Pakistan are classified as intermediate exposure and low exposure banks, respectively. The higher the exposure of banks, the more they are expected to transmit financial shock to the local market. This classification is similar to that of Schnabl (2012), who classifies banks into these categories and then measures the impact of lending changes by each type of bank to firms in Peru. In Table 1, we provide the list of banks in our dataset along with their average market share measured as average total assets as a percent of average total assets of all the banks for the period from 2006 to 2011 in our dataset. We also provide average borrowing outside Pakistan as a percent of total borrowing for the period from 2006 to 2011. We observe international exposure of banks from zero to $22.3 \%$ and there is enough variation in the sample to exploit the transmission of global

\footnotetext{
${ }^{17}$ For example, if firm A borrows from bank B in two ways through products $\mathrm{Y}$ and $\mathrm{Z}$, we then consolidate the borrowing from bank B with respect to both the products, so there will be two observations from bank B: one w.r.t product $\mathrm{Y}$ and the other w.r.t Z. In this way we are able to ascertain the changes in lending of the various product types in our analysis.
} 
financial crisis shock.

(Insert Table 1 about here)

In addition to our core proxies, we use a number of control variables, which have been shown to influence the change in bank lending to real firms. We focus on bank and borrower/loan characteristics and follow the literature (see, for example, Khwaja and Mian, 2008; Schnabl, 2012; Baele et al., 2014; Zaheer and Farooq, 2015) when selecting and measuring these controls. Kapan and Minoiu (2013) show that better capitalized and more liquid banks were better able to continue credit supply during the 2007-2008 crisis. Building on this finding, we use the bank capital ratio as a proxy for solvency, and the liquid assets to total assets ratio as a proxy for bank liquidity. In addition, we add the natural log of the number of branches as a control variable, as the branch network is one of the factors leading to bank runs during a crisis (He and Manela, 2012). Furthermore, the size of bank may also affect changes in lending, because larger banks are typically considered to be more stable. We use total bank assets as a proxy for the size of the bank. For borrower/loan characteristics, we use size of loan as the proxy for the size of the borrower. In addition to loan size, we also consider other loan characteristics including loan maturity, whether the loan is secured, and whether it is a performing loan. Loan maturity can have a negative impact on the change in lending if banks do not want to commit a large amount of funds over a long term. Similarly, security for the loan, and whether the loan is performing, are also important because they may have an effect on the lending ability of banks. Finally, we also use loan type dummies, bank controls and firm fixed effects for some regressions as robustness checks. Details of the variables used in the paper and their definitions are given in Appendix Table 2.

\section{Methodology}

This section outlines the econometric setting that we use to estimate the transmission of bank financial shocks to real firms. This estimation poses a key empirical identification problem arising from changes in credit supply by Pakistani banks, and credit demand by Pakistani firms. For example, a reduction in lending by a bank to a firm may reflect a credit supply shortage in the bank, lower credit demand from the firm, or a combination of both. More specifically, if an export-oriented local firm (e.g., Nishat Mills) borrows more from a foreign bank (e.g., Citibank), and its export opportunities decrease following the global financial crisis, then Nishat Mills might reduce borrowing from Citibank, and Citibank's lending may 
decrease relative to a local bank (e.g., United Bank Limited). To address this potential identification problem, we follow Khwaja and Mian (2008) and Schnabl (2012) and use firm fixed effects and consider the fact that the same firm borrows from more than one bank. Our analysis controls for the changes in credit demand at the firm level by checking for loan relationships within firms, rather than across firms. Thus if a firm is borrowing from both bank A and bank B, we check for the changes in borrowing from bank A relative to bank B by the same firm. Using this approach we are able to identify the changes in credit demand by firms due to the changes in credit supply from banks.

We implement the following strategy for identification using the Ordinary Least Squares (OLS) method. We start with baseline model of Schnabl (2012), which is as follows:

$$
\Delta \mathrm{L}_{\mathrm{ijb}}=\boldsymbol{\beta}_{\mathrm{j}}+\boldsymbol{\beta}_{\mathbf{l}} \mathbf{E}_{\mathrm{b}}+\varepsilon_{\mathrm{ijb}}
$$

The dependent variable in equation (1), $\Delta \mathrm{L}_{\mathrm{ijb}}$ is the change in loan $\mathrm{i}$ of firm $\mathrm{j}$ from bank $\mathrm{b}$ which shows the changes in borrowing by a firm from a bank prior to and after the financial shock. The right hand side of the above equation includes $\beta_{1}$ which are firm fixed effects that absorb all firm specific credit demand shocks, while $\mathrm{E}_{\mathrm{b}}$ denotes exposure of the bank to a financial shock. We identify bank exposure in three categories: high, intermediate and low. In order to include the control variables and other variables of interest we extend the baseline model (1) and estimate the following model (2):

$$
\Delta \mathrm{L}_{\mathrm{ijb}}=\beta_{1}+\beta_{2} \mathrm{E}_{\mathrm{b}}+\beta_{3} \mathrm{X}_{\mathrm{bt}}+\beta 4 \mathrm{Y}_{\mathrm{i}, \mathrm{j}}+\beta_{5} \mathrm{Z}_{\mathrm{t}}+\varepsilon_{\mathrm{ijb}} \quad \ldots-\ldots-(2)
$$

$\beta_{2}$ in model (2) is the coefficient of interest and checks the transmission of a financial shock after controlling for credit-demand shocks at the firm level. The key assumption in the analysis is that all firms reduce their lending in equal proportions from all banks after the credit crunch. This assumption is plausible for both high and intermediate exposure banks due to their similar characteristics, but not for low exposure banks. Therefore, we control for bank characteristics $\left(\mathrm{X}_{\mathrm{bt}}\right)$ in our analysis. The sample is restricted to firms that borrow from more than one bank prior to the shock. As the specification includes firm fixed effects, the coefficient of interest is calculated only for firms that borrow from more than one bank. In addition to the bank characteristics, we also control for borrower/loan characteristics ( $\left.\mathrm{Y}_{\text {it }}\right)$ 
and macroeconomic variables $\left(\mathrm{Z}_{\mathrm{t}}\right)$ to capture any borrower/loan and macroeconomic factors that might have an impact on changes in loan $\mathrm{i}$ of firm $\mathrm{j}$ from bank $\mathrm{b}\left(\Delta \mathrm{L}_{\mathrm{ijb}}\right)$.

\section{Empirical Results}

\subsection{Descriptive statistics}

Table 2 provides descriptive statistics for 33,245 loans to 11,524 borrowers from 21 banks; these are also reported by exposure type. The high and intermediate exposure banks are similar in number, but the intermediate ones are larger in size, which can be seen by the average of total assets for both categories, which are PKR 42,412 million $^{18}$ and PKR 47,868 million respectively. Low exposure banks are quite small in size compared to the high and intermediate exposure ones. Liquid assets are approximately $14.1 \%, 19.8 \%$ and $13.2 \%$ of total assets for the high, intermediate and low exposure banks, respectively, making intermediate exposure banks the most liquid of all the categories. However, the high exposure banks are the best capitalized, and the mean capital ratios for the high, intermediate and low exposure banks are $15.4 \%, 13.8 \%$ and $11.6 \%$, respectively. It is interesting to see if high exposure banks transmit shocks to firms despite being the best capitalized. The presence of intermediate exposure banks is greater, with a median of 1,078 branches, compared to high exposure banks with a median of 994 branches, and low exposure banks with 122. This shows that most of the big banks with large branch networks fall into the category of intermediate exposure. The highest percentage in the high exposure category is that of privatized banks with $73.9 \%$, followed by foreign banks with $14.4 \%$. In the intermediate exposure category, the largest percentage is that of nationalized banks, at $43.5 \%$, followed by private banks at $28.6 \%$. However, the low exposure banks are mostly private banks, with $61.6 \%$ of the total banks, followed by privatized banks with $18.5 \%$. We observe that the characteristics of the high, intermediate and low exposure banks are quite similar with regard to the highest number of loans being term loans, followed by export loans.

(Insert Table 2 about here)

\subsection{Bank lending channel}

${ }^{18} 1$ USD 124 PKR, 1 EUR 146 PKR and 1 GBP 163 PKR on 31 $1^{\text {st } J u l y ~} 2018$. 
The findings related to the transmission of financial shocks to real firms are reported in Table 3. Column 1 shows our baseline results. The results provide support for our theoretical argument, which is consistent with Schnabl (2012) that intermediate and low exposure banks increased their lending because of the international financial shock post-GFC. The low exposure banks increased their lending more than the intermediate exposure ones. This is consistent with our hypothesis that the less that banks are exposed internationally, the lower the shock they transmit to the real economy. However, when we include bank, borrower, loan and macroeconomic controls in our model (equation 2), as shown in columns 2, 3 and 4 of Table 3, the intermediate exposure banks increase their lending to firms more than the low exposure ones. ${ }^{19}$ This is perhaps due to the fact that intermediate exposure banks are the most liquid of all the categories and are able to withstand international financial shocks. The magnitude and statistical significance of the coefficients of the other control variables are mostly in line with the literature. We find positive coefficients for capital ratio, meaning that the better capitalized banks increased their lending after the crisis, confirming the findings of Kapan and Miniou (2013) that better capitalized banks can better withstand shock. However, we find negative coefficients for the liquid assets to total asset ratio, showing that the more liquid banks reduce their lending after the financial shock. We find that the big banks provide more lending to big borrowers after the shock, as shown by the positive significant coefficients of the natural logarithm of total assets, as well as the natural logarithm of loan size. The banks with large branch networks reduced their lending after the financial shock.

In column 3, we run the same regression as in column 2 but with macronomic variables. We add macroeconomic variables like GDP growth and natural logarithm of manufacturing production $^{20,21}$ to control for the effect of economic contraction/recession. ${ }^{22}$ We find negative relationship with both the economic variables indicating that economic contraction/recession indeed leads to reduction in lending after the financial shock. Overall we find the same results

\footnotetext{
${ }^{19}$ This is contrary to Schanbl (2012). However, when we use advances outside Pakistan to determine the international exposure of banks, we find similar results.

${ }^{20}$ We restrict ourselves to using only GDP growth and natural logarithm of manufacturing production because of high correlation with other macroeconomic variables.

${ }^{21}$ We also use other macroeconomic variables like CPI, natural logrithm of manufacturing production and unemployment rate that show mild correlation. The results, not reported here, remain robust with the inclusion of these macroeconomic variables. Furthermore, despite high correlation we use all the macroeconomic variables like GDP growth, CPI, natural logrithm of manufacturing production, unemployment rate, natural logarithm of trade deficit, interest rate and natural logarithm of broad money. Our results, not reported here, remain consistent even with the inclusion of all these macroeconomic variables.
}

${ }^{22}$ We thank the anonymous reviewer for highlighting this very important point. 
as in Column 2 but the coefficients of the intermediate and low exposure banks are smaller in magnitude. Moreover, all the control variables keep the same sign, except the coefficient of natural logarithm of maturity and secured loans. In column 4, we show the bank lending channel using complete model with all the controls and firm fixed effects. The coefficients of both the intermediate and low exposure banks slightly increase in magnitude compared to the results in column 3. However, all the control variables remain the same economically and statistically. This indicates that the changes in lending can only be explained by the financial shock.

(Insert Table 3 about here)

In order to find the lending effect of "pure" domestic banks which do not have international borrowing, we classify banks in a control group and in a treatment group. ${ }^{23}$ Control group includes purely "domestic" banks ${ }^{24}$ which do not borrow internationally at all and treatment group includes "foreign" banks that do have international borrowing. We keep the structure of the regression models same as in Table 3. The results reported in Table 4 show that treatment group, "foreign" banks being international borrower, transmit the financial crisis shock and reduce lending after the crisis.

(Insert Table 4 about here)

\subsection{Extensive margin results}

Following Khwaja and Mian (2008) and Jimenez et al. (2012, 2014), we also study whether the financial shock had an impact on the extensive margin of banks, by forcing firms to exit the market or reducing the entry of new firms. The results are reported in Table 5. We define 'Exit' to be equal to 1 if the loan is not renewed at some point during the GFC period. We use all the bank and borrower/loan characteristics and loan type controls in all our regressions. As previously, we start our analysis with firm fixed effects to control for changes in demand at the firm level. The results are shown in column 1 of Table 5 . We find that a one standard deviation increase in borrowing from intermediate and low exposure banks reduces exits by 1.06 percentage points. In addition, we run a non-linear probit model, whose results are reported in column 2. Economically, the results are stronger than FE model. Overall, we conclude that

\footnotetext{
${ }^{23}$ We thank the anonymous reviewer for highlighting this very important point.

${ }^{24}$ We also make two different control groups. In one group, we classify banks as "domestic" if their international borrowing is less than $0.5 \%$ and in the other group; we classify banks as "domestic" if their international borrowing is less than $1 \%$. Our results remain consistent with these two additional classifications.
} 
firms borrowing from intermediate exposure banks are less likely to exit the market after the financial shock, and that this likelihood is even lower if they borrow from low exposure banks.

In columns 3 and 4 of Table 5, we show banks' ability to make new loans. We use 'Entry' as a dependent variable to study this, defined as 1 if a new loan is made after the financial shock (during the period from April 2009 to March 2011). Again, we use all the bank and borrower/loan characteristics and loan type controls in all of our regressions. Similarly, we also run FE and non-linear probit models to study this. In column 3, we show the results of our preferred FE model and find that a one standard deviation increase in borrowing from intermediate exposure banks increases the entry of firms by 1.01 percentage points (the results are not statistically different from zero) and by 1.02 points in the case of low exposure banks. Similar to what was observed in the results for 'Exit', the results are stronger for the non-linear probit model. Overall, we find that firms borrowing from low exposure banks are more likely to obtain new loans after a financial shock, and that this likelihood is higher if they borrow from intermediate exposure banks.

\section{(Insert Table 5 about here)}

We further extend our analysis of the extensive margin to observe if the impact of financial shock on the 'Exit' and 'Entry' of small firms is the same. For this, we combine the proxies of the intermediate and low exposure banks, terming them 'Relatively low' exposure banks. The results are reported in Table 6 . In column 1 of Table 6 , we run regression with only the 'Relatively low' proxy, and find that the effect is same as that shown by the intermediate and low exposure proxies separately. Since most of the small firms have only one bank relationship, we run OLS regression and report the results in column 4; for comparison, we run FE regression in column 2 . We obtain very similar results in both models, showing that small firms are more likely to exit the market after a financial shock. However, the interaction between 'small firms' and 'relatively low' exposure firms still gives a negative sign, but only statistically significant in FE regression, indicating that small firms borrowing from relatively low exposure banks are less likely to exit the market. To be consistent with Table 5, we also run a non-linear probit model and find very similar results. With regard to entry into the loan market, small firms are less likely to obtain a new loan after the financial shock. However, our results are not statistically different from zero if they borrow from relatively low exposure banks. The results are economically the same if we run a non-linear probit model. Overall, our results are consistent with previous research that small firms are adversely affected during a financial 
shock (Petersen and Rajan, 1994; Berger and Udell, 1995, 2002). However, our results are different from Khwaja and Mian (2008) in this particular context of the extensive margin for small firms. They find no difference between smaller and larger firms, whereas we find that smaller firms are adversely affected during the financial shock. One possible explanation in our setting is that the quantum of the shock originating from GFC is much higher than the domestic liquidity shock after the nuclear tests of May 1998 by Pakistan, as studied by Khwaja and Mian (2008).

(Insert Table 6 about here)

\subsection{Bank lending channel for small firms}

In Table 3, we found interesting results for the intensive margin of small firms. We therefore extend the analysis of Table 3 to small firms, and show the corresponding results of the bank lending channel in Table 7. Our dependent variable is the same as in Table 3, i.e., the log change in bank lending during the crisis. In column 1 of Table 7, we start with our full FE model, as in column 3 of Table 3, meaning that we include all the bank and borrower/loan characteristics, together with loan type dummies, bank control and macroeconomic variables, but we use our new combined proxy of 'Relatively low' exposure banks. We find a positive coefficient (Tabe 7, column 1) showing that relatively low exposure banks increased their lending after the financial crisis. However, we can see from the statistically significant negative sign in column 2 that lending to small firms was reduced during the financial crisis. We also do not find any significant effect if smaller firms borrowed from relatively low exposure banks. As explained above, since most of the small firms have only one relationship, we run OLS regression in column 4 to study the bank lending channel for small firms. The results are stronger, confirming our argument that smaller firms mostly borrow from only one bank. This also shows that the variation in lending by relatively low exposure banks across firms is higher than the variation in lending within firms. These results are consistent with those of Khwaja and Mian (2008) and Schnabl (2012), showing that lending to small firms is affected more by the major banks after an exogenous shock in the domestic market.

(Insert Table 7 about here)

\subsection{Bank lending channel for different bank types}

We now turn our attention to checking the impact of exogenous shock on the different bank types in Pakistan, and report the results in Table 8. Private and privatized banks make the 
highest percentage of loans in Pakistan. We call privatized banks as "Big banks" in Table $8 .{ }^{25}$ We therefore check whether there are any differences if these are relatively low or high exposure banks. We classify small local banks as private banks, contrary to the list issued by the State Bank of Pakistan. ${ }^{26}$ We exclude the top four big banks from this list and show their bank lending channels separately. The results for private banks are reported in columns 1 and 2 of Table 8. We can see from the 'Private bank' dummy that this type of bank increases lending after the financial shock. However, if these private banks are relatively low exposure banks, they reduce their lending after the financial shock. The results remain the same without firm fixed effects when we run OLS regression in column 3. Next, we devise a 'Big bank' dummy equal to 1 if the bank is one of the four big banks. As expected, big (privatized) banks reduced their lending to real firms after the financial shock, whereas these banks increased their lending if they are relatively low exposure banks. The results are quite intuitive, and show that big highly exposed banks transmit financial shock to real firms.

(Insert Table 8 about here)

\subsection{Bank lending channel for different loan types}

Following Schnabl (2012), Farooq and Zaheer (2015) and Berg and Kirschenmann (2015), we study the bank lending channel via export loans, Islamic loans ${ }^{27}$ and agricultural loans. The results are reported in Table 9. Columns 1 and 2 of Table 9 do not find any change in lending by both relatively low and high exposure banks. These results are similar to those of Schnabl (2012) because he also does not find any change in lending by either intermediate or low exposure banks for exporters. However, he finds that intermediate exposure banks increase lending to non-exporters after the liquidity shock. ${ }^{28}$

Next, in columns 3 and 4 of Table 9, we show the change in lending by Islamic Banks. In Pakistan, conventional and Islamic banking co-exist. Islamic Banking refers to a system of banking or banking practices that are consistent, both in objectives and operations, with the Shari'ah. As highlighted by Baele et al. (2014), the key distinguishing features of Islamic

\footnotetext{
${ }^{25}$ As noted before, top four big privatized banks have about $41 \%$ of the market share.

${ }^{26} \mathrm{http}: / /$ sbp.org.pk/f_links/index.asp

${ }^{27}$ Note there are Islamic branches of conventional banks in Pakistan, so there are loans extended by these branches.

${ }^{28}$ When we split the sample into intermediate exposure and low exposure banks, as done by Schnabl (2012), we find very similar results - that our findings for exporters are not statistically significant for either intermediate or low exposure banks and for non-exporters; both intermediate and low exposure banks increase their lending. We do not report these results due to limited space.
} 
Banking, the prohibition of interest (riba), excessive leverage, and its focus on risk sharing, may make Islamic banks quite different from conventional banks. ${ }^{29}$ Some papers look at the comparative performance of Islamic and conventional banks during the GFC (for example, Hasan and Dridi, 2010; Beck et al., 2013; Farooq and Zaheer, 2015). They conclude that Islamic banks performed better in terms of profitability, intermediation ratio, asset quality and resilience to financial shocks. Our analysis is closely related to that of Farooq and Zaheer (2015), who use bank level data and show that Islamic banks granted more loans during financial crisis. We use loan level data to look at the same impact; however, in our case the financial panic is not home grown, but comes from abroad. Furthermore, we look at how different exposure banks make Islamic loans. Contrary to Farooq and Zaheer (2015), we do not find that banks granted more Islamic loans during periods of GFC as can be seen from the 'Islamic loan' dummy, as well as the interaction between 'Islamic loan' and 'relatively low' in columns 3 and 4 of Table 9. In unreported results we find that the results are sentitive to the inclusion of macroeconomic variables. With the exclusion of macroeconomic variables, we find that banks grant more Islamic loans during the financial shock but relatively low exposure banks reduce advancing Islamic loans. This finding shows that the granting of Islamic loans is dependent on the economic contraction/recession. A severe shock has stronger impact on the behaviour of Islamic banks while granting Islamic loans. Overall, we see that the impact of a financial shock on Islamic loans is similar to conventional loans. This finding is similar to those of Bader et al. (2008) and Chong and Liu (2009).

Finally, in columns 5 and 6 of Table 9, we conduct analysis of agricultural loans. As highlighted by Berg and Kirschenmann (2015) in the context of Azerbaijan, agriculture is a very local sector for an agriculture-based economy. Lending to such a sector is thus expected to be immuned to any global financial shock. Similar to Azerbaijan, Pakistan is also an agriculturebased economy and our dataset allows us to segregate loans given for agricultural purposes. We devise an 'Agri' dummy equal to 1 if the loan is given for such purposes. Contrary to economic theory, we find that even loans to the agriculture sector decreased following the financial shock, as can be seen from the negative and statistically significant coefficient 'Agri' in column 5 of Table 9. However, the relatively low exposure banks increased their granting of agricultural loans.

\footnotetext{
${ }^{29}$ Consistent with the Credit Information Bureau (CIB) of the State Bank of Pakistan, we use the term Islamic banking for banks operating as Islamic banks as per the definition given above; all other banks being conventional banks.
} 
(Insert Table 9 about here)

\subsection{Bank lending channel and information asymmetry}

One of the contributions of this paper is the results shown in Table 10, which represent the impact of information asymmetry on the changes in lending to firms during the GFC. We devise direct proxies of information asymmetry following Sufi (2007), Bharath et al. (2011) and Chaudhry and Kleimeier (2015) and observe the bank lending channel via information asymmetry between the borrower and lender. Our first proxy is the natural log of $1+$ number of previous loans ' $\operatorname{Ln}(1+$ no of previous loans $)$ '. This proxy relates to the borrower's reputation in the credit market and whether this reputation has any impact on changes in lending after the financial shock. The results are reported in column 1 of Table 10. We do not find any impact of borrower reputation on the lending decision of banks, as can be seen from the statistically insignificant coefficient of ' $\operatorname{Ln}(1+$ no of previous loans $)$ '. Since we do not find any significance, we do not make any further analysis of borrower reputation.

Next, using the market share of deposits as a proxy for bank reputation, we assume that the banks with a higher reputation would perhaps not reduce their lending following the financial shock, due to a fear of loss of reputation and hence their share of deposits. Contrary to our hypothesis, we find that highly reputed banks reduce their lending after a financial shock and are not able to withstand the financial shock by themselves. However, we do not find any significant impact if these reputed banks have relatively low exposure. The results are given in columns 2 and 3 of Table 10 .

Following Sufi (2007), we distinguish the presence of information asymmetry by using a relationship dummy. We code 'relationship' equal to 1 if the borrower has previously obtained a loan from the same bank. Here, we want to see if previous interaction between the bank and the borrower reduces information asymmetry and that the bank can withstand the financial shock and is able to increase lending. We expect to find a positive sign for the 'relationship' proxy if the information about the borrower is so positive that it can overcome the negative financial shock. We do not find any statistically significant impact of only 'relationship' dummy but we do find positive and significant impact of the interaction of relationship with the relatively low exposure banks in columns 4 and 5 of Table 10. This indicates that the information abou the borrower is so positive that it is able to overcome the negative financial 
shock. We find very similar results when we use the REL number proxy proposed by Bharath et al. (2011). The REL number is defined as the ratio of number of loans advanced by a bank to a borrower and the total number of loans advanced by that bank. Overall, the results from this table are consistent with our main results that only relatively low exposure banks are able to withstand the financial shock.

(Insert Table 10 about here)

\section{Conclusion}

As small developing countries may be more vulnerable to exogenous economic shocks due to inherent political instability and financial risk, it is important to analyze the impact of the financial crisis on real businesses in those economies. Moreover, in the absence of fully developed capital and financial markets, most local businesses rely heavily on bank financing in developing markets. The small and medium enterprises that form the core of emerging markets may also suffer due to the shortage of funds from banks and other financial institutions as a result of exogenous economic shocks.

Studying the Pakistani market as a case in point, and capitalizing on the unique dataset of all corporate loans, we have identified changes in post-financial shock lending using various bank and loan level variables. We have shown that lending to small firms and lending by private banks decreased, irrespective of the fact whether they borrowed from low or high exposure banks. However, lending by relatively low exposure big banks increased after the global financial crisis. The findings regarding different types of loans revealed that Agricultural loans increased after the financial shock (i.e., GFC), both from relatively low exposure banks. Our findings on information asymmetry showed that bank reputation as a proxy for information asymmetry was not able to overcome information asymmetry problems and that high exposure banks still reduced their lending after the financial shock. However, previous interactions of the borrower with relatively low exposure banks were able to overcome these problems and increased their lending after the GFC.

Our work is important from a regulatory perspective as it identifies that emerging markets are open to shocks from the international financial markets, despite their limited linkages with them, hence mechanisms need to be developed to better cope with any such events in the future. This brings us to areas for further research; first, we would like to check the impact of financial shock on the interbank market of Pakistan, to see whether the liquidity crunch only affected 
firms, or also interbank liquidity. Another interesting potential area of research could be on the regulatory side, observing the current funding structures of banks in the country and devising a set of guidelines outlining limits to international exposure. 


\section{REFERENCES}

Ali, M. M. (2009). Global financial crisis: Impact on Pakistan and policy response. Speech at Regional High-Level Workshop on " Strengthening the Response to the Global Financial Crisis in Asia-Pacific: The Role of Monetary, Fiscal and External Debt Policies', UN ESCAP.

Almeida, H., Campello, M., Laranjeira, B. \& Weisbenner, S. (2009). Corporate debt maturity and the real effects of the 2007 credit crisis. National Bureau of Economic Research, No. w14990.

Ashcraft, \& Adam, B. (2001). New evidence on the lending channel. FRB of New York Staff Report 136.

Bader, M. K., Mohamad, S., Ariff, M. \& Hassan, T. (2008). Cost, revenue, and profit efficiency of Islamic versus conventional banks: international evidence using data envelopment analysis. Islamic Economics Studies, 15(2), 24-76.

Baele, L., Farooq, M. \& Ongena, S. (2014). Of religion and redemption: Evidence from default on Islamic loans. Journal of Banking \& Finance, 44, 141-159.

Beck, T., A. Demirgüç-Kunt \& Merrouche, O., (2013). Islamic vs. conventional banking: Business model, efficiency and stability. Journal of Banking \& Finance, 37, 433-447.

Bekaert, G., Harvey, C. R. \& Lundblad, C. (2005). Does financial liberalization spur growth? Journal of Financial Economics, 77(1), 3-55.

Berg, G. \& Kirschenmann, K. (2015). Funding versus real economy shock: The impact of the 2007-09 crisis on small Firms' credit availability. Review of Finance, 19(3), 951-990.

Berger, A. N. \& Udell, G. F. (1995). Relationship lending and lines of credit in small firm finance. Journal of Business, 68(3), 351-381.

Berger, A. N. \& Udell, G. F. (2002). Small business credit availability and relationship lending: The importance of bank organisation structure. Economic Journal, 112(477), 32-53.

Berger, A. N., \& Bouwman, C. H. (2013). How does capital affect bank performance during financial crises? Journal of Financial Economics, 109(1), 146-176.

Bernanke, B. S. \& Blinder, A. S. (1988). Credit, money, and aggregate demand. National Bureau of Economic Research, No. w2534.

Bernanke, B. S. \& Gertler, M. (1995). Inside the black box: The credit channel of monetary policy transmission. Journal of Economic Perspectives, 9, 27-48.

Bernanke, B. S. (1983). Non-monetary effects of the financial crisis in the propagation of the Great Depression. National Bureau of Economic Research, No. w1054. 
Bernanke, B. S., \& Blinder, A. S. (1992). The federal funds rate and the channels of monetary transmission. American Economic Review, 901-921.

Bernanke, B. S., Gertler, M. \& Gilchrist, S. (1996). The flight to quality and the financial accelerator. Review of Economics and Statistics, 78(1), 1-15.

Bharath, S.T., Dahiya, S., Saunders, A. \& Srinivasan, A., (2011). Lending relationships and loan contract terms. Review of Financial Studies, 24 (4), 1141-1203.

BIS. (2011). The transmission channels between the financial and real sectors: a critical survey of the literature. Bank for International Settlements, Basel, Working paper no. 18.

Blanchard, O., Dell'Ariccia, G., \& Mauro, P. (2010). Rethinking macroeconomic pmmolyolicy. Journal of Money, Credit and Banking, 42, 199-215.

Bryant, R., Hooper, P. \& Mann, C. (1993). Evaluating policy regimes: New empirical research in empirical macroeconomics, Brookings Institution, Washington D.C.

Campello, M., Graham, J. R. \& Harvey, C. R. (2010). The real effects of financial constraints: Evidence from a financial crisis. Journal of Financial Economics, 97(3), 470-487.

Cecchetti, S. G. (1995). Distinguishing theories of the monetary transmission mechanism. Review-Federal Reserve Bank of Saint Louis, 77, 83-83.

Cetorelli, N. \& Goldberg, L. (2012). Banking globalization and monetary transmission. The Journal of Finance, 67(5), 1811-1843.

Chaudhry, S. M. \& Kleimeier, S. (2015). Lead arranger reputation and the structure of loan syndicates. Journal of International Financial Markets Institutions and Money, 38, 116-126.

Chong, B. S. \& Liu, M.H. (2009). Islamic banking: interest-free or interest-based? PacificBasin Finance Journal, 17(1), 125-144.

Corsetti, G., Pericoli, M. \& Sbracia, M. (2005). Some contagion, some interdependence: More pitfalls in tests of financial contagion. Journal of International Money and Finance, 24(8): 1177-1199.

De Haas, R. \& Van Horen, N. (2013). Running for the exit: International bank lending during a crisis. Review of Financial Studies, 26, 244-85.

Derviz, A. \& Podpiera, J. (2007). Cross-border lending contagion in multinational banks, ECB Working Paper No 807.

Dungey, M. \& Gajurel, D. (2015). Contagion and banking crisis - International evidence for 2007-2009. Journal of Banking \& Finance, 60, 71-79. 
Eichengreen, B., Rose, A. K. \& Wyplosz, C. (1996). Contagious currency crises. National Bureau of Economic Research. No. w5681.

Farooq, M. \& Zaheer, S. (2013). On the co-existence of conventional and Islamic banks: Do they differ in business structure, in Zaheer, S. ed. Financial intermediation and monetary transmission through conventional and Islamic channels. University van Amsterdam (Dissertation) pp. 41-61.

Farooq, M. \& Zaheer, S. (2015). Are Islamic banks more resilient during financial panics? International Monetary Fund Working Paper, WP/15/41.

Farooq, M., Zaheer S. \& Wijnbergen, S. (2013). Capital structure, risk shifting and stability: Conventional and Islamic banking, in Zaheer, S. ed. Financial intermediation and monetary transmission through conventional and Islamic channels. University van Amsterdam (Dissertation) pp. 63-88.

Forbes, K. J. \& Chinn, M. (2004). A decomposition of global linkages in financial markets over time. Review of Economics and Statistics, 86(3), 705-722.

Forbes, K. J. \& Rigobon, R. (2002). No contagion, only interdependence: measuring stock market comovements. Journal of Finance, 57(5), 2223-2261.

Forbes, K. J. (2001). Are trade linkages important determinants of country vulnerability to crises? In: S Edwards and J. Frankel, eds., Preventing currency crises in emerging markets. University of Chicago Press, Chicago.

Forbes, K. J. (2004). The Asian flu and Russian virus: The international transmission of crises in firm level data. Journal of International Economics, 63(1), 59-92.

George R.G. Clarke, Cull. R. \& Kisunko, G. (2012). External finance and firm survival in the aftermath of the crisis: evidence from Eastern Europe and Central Asia. Journal of Comparative Economics, 40 372-392.

Giannetti, M. \& Laeven, L. (2012). The flight home effect: Evidence from the syndicated loan market during financial crises. Journal of Financial Economics, 104(1), 23-43.

Hasan, M. \& Dridi, J. (2010). The effects of the global crisis on Islamic and conventional banks: A comparative study, IMF Working Paper 10/201 (Washington DC: International Monetary Fund).

He, Z. \& Manela, A. (2012). Information acquisition in rumor-based bank runs, Working Paper No. 18513. Cambridge: National Bureau for Economic Research.

Hubbard, R. G. (1995). Is there a 'credit channel' for monetary policy? Federal Reserve Bank of St. Louis Review 77, 63-74. 
Ivashina, V . \& Scharfstein, D. (2010). Bank lending during the financial crisis of 2008. Journal of Financial economics, 97(3), 319-338.

Iyer, R., Lopes, S., Peydro, J.-L \& Schoar, A. (2014). Interbank liquidity crunch and the firm credit crunch: Evidence from the 2007-2009 Crisis. Review of Financial Studies, 27, 347-372.

Jiménez, G, Ongena, S., Peydró J., \& Saurina, J. (2012). Credit supply and monetary policy: Identifying the bank balance sheet channel with loan applications. American Economic Review, 102 (5), 2301-2326.

Jiménez, G, S. Ongena, J. Peydró \& Saurina, J. (2014). Hazardous times for monetary policy: What do twenty-three million bank loans say about the effects of monetary policy on credit risk? Econometrica, 82, 463-505.

Jotikasthira, C., Lundblad, C. \& Ramadorai. T. (2013). How do foreign investors impact domestic economic activity? Evidence from India and China. Journal of International Money and Finance, 39, 89-110.

Kapan, T. \& Minoiu, C. (2013). Balance sheet strength and bank lending during the global financial crisis, IMF working paper 13/102, International Monetary Fund.

Kashyap, A. K. \& Stein, J. C. (1994). Monetary policy and bank lending. In Monetary policy (pp. 221-261). The University of Chicago Press.

Kashyap, A. K., \& Stein, J. C. (2000). What do a million observations on banks say about the transmission of monetary policy? American Economic Review, 90(3), 407-428.

Kashyap, Anil, Owen L., \& Stein, J., (1994), Credit conditions and the cyclical behavior of inventories. Quarterly Journal of Economics, 109, 565-592.

Khwaja, A. I. \& Mian, A. (2008). Tracing the impact of bank liquidity shocks: Evidence from an emerging economy. American Economic Review, 98(4), 1413-1442.

Kleimeier, S., Lehnert, T. \& Verschoor, W. F. C. (2008). Measuring financial contagion using time-aligned data: the importance of the speed of transmission of shocks. Oxford Bulletin of Economics and Statistics, 70-4.

MacDonald, R., \& Taylor, M. P. (1993). The monetary approach to the exchange rate: rational expectations, long-run equilibrium, and forecasting. Staff Papers, 40(1), 89-107.

Mian, A. (2006). Distance constraints: The limits of foreign lending in poor economies. Journal of Finance, 61, 1005-1056.

Mishkin, F. S., Matthews, K. \& Giuliodori, M. (2013). The economics of money, banking and financial markets. Pearson Education Limited. Harlow. 
Modigiliani, M. (1975). Monetary policy and consumption, In: Consumer spending and money policy: The linkages, Federal Reserve Bank, Boston.

Nasir, M. Z. (2012). Financial sector reforms in Pakistan. In: Economic reform process in South Asia: Toward policy efficiency. Ed (Dee, Philippa). Routledge, Oxon.

Oliner, S. D. \& Rudebusch, G. D. (1996). Monetary policy and credit conditions: evidence from the composition of external finance: comment. American Economic Review, 300-309.

Paravisini, D. (2008). Local bank financial constraints and firm access to external finance. Journal of Finance, 63(5), 2161-2193.

Paravisini, D., Rappoport, V., Schnabl, P. \& Wolfenzon, D. (2015). Dissecting the effect of credit supply on trade: Evidence from matched credit-export data. Review of Economic Studies, 82(1), 333-359.

Peek, J., \& Rossenberg, E. (1997). The international transmission of financial shocks: The case of Japan. American Economic Review, 87, 495-505.

Petersen, M. A. \& Rajan, R. G. (1994). The benefits of lending relationships: Evidence from small business data. Journal of Finance, 49(1), 3-37.

Schnabl, P. (2012). The international transmission of bank liquidity shocks: Evidence from an emerging market. Journal of Finance, 67(3), 897-932.

Sufi, A. (2007). Information asymmetry and financing arrangements: Evidence from syndicated loans. Journal of Finance, 62(2), 629-668.

Taylor, J. (1995). The monetary transmission mechanism: An empirical framework. Journal of Economic Perspectives, 9, 11-26.

Zia, B.H. (2008). Export incentives, financial constraints, and the (mis)allocation of credit: micro-level evidence from subsidized export loans. Journal of Financial Economics, 498-527. 
Table 1

List of Pakistani banks, the ir market share and their borrowing outside Pakistan

This table provides average market share by total assets and average borrowing outside Pakistan by Pakistani banks from 2006 to 2011. Column (1) lists the all the banks in our dataset ranked by market share. Column (2) reports the market share and Column (3) reports borrowing outside Pakistan by Pakistani banks as a percent of total borrowing.

\begin{tabular}{|c|c|c|}
\hline Pakistan Banks & $\begin{array}{c}\text { Market } \\
\text { Share }\end{array}$ & $\begin{array}{c}\text { Borrowing } \\
\text { Outside } \\
\text { Pakistan } \\
\end{array}$ \\
\hline$(1)$ & (2) & (3) \\
\hline National Bank of Pakistan & 16.92 & 7.60 \\
\hline Habib Bank Limited & 15.48 & 22.30 \\
\hline United Bank Limited & 10.71 & 7.30 \\
\hline MCB Bank Limited & 8.44 & 9.60 \\
\hline Allied Bank of Pakistan & 7.60 & 0.70 \\
\hline Standard Chartered Bank Pakistan Limited & 5.85 & 8.90 \\
\hline Askari Bank Limited & 4.70 & 0.40 \\
\hline The Bank of Punjab & 4.58 & 0.50 \\
\hline NIB Bank & 4.04 & 0.40 \\
\hline Habib Metropolitan Bank Limited & 3.85 & 2.50 \\
\hline Faysal Bank Limited & 3.40 & 0.60 \\
\hline Bank Alhabib Limited & 3.03 & 4.80 \\
\hline Meezan Bank & 2.85 & 0.90 \\
\hline Royal Bank of Scotland & 2.72 & 0.10 \\
\hline Soneri Bank Limited & 1.70 & 8.80 \\
\hline BankIslami Pakistan Limited & 0.85 & 0.00 \\
\hline KASB Bank Limited & 0.82 & 6.00 \\
\hline AlBaraka Bank Pakistan Limited & 0.82 & 16.70 \\
\hline Mybank Limited & 0.75 & 1.70 \\
\hline The Bank of Khyber & 0.71 & 1.20 \\
\hline First Women Bank Limited & 0.20 & 0.00 \\
\hline
\end{tabular}


Table 2

Descriptive statistics

This table presents descriptive statistics for 33,245 loans to 11,524 borrowers by 21 banks. These loans are further divided by exposure type. High, Medium and Low exposure banks. The banks with over $8 \%$ of their borrowings outside Pakistan are classified as high exposure banks, the banks between $4 \%$ to $8 \%$ borrowings outside Pakistan are classified as intermediate exposure and the banks with less than $4 \%$ borrowings outside Pakistan are classified as low exposure banks. All the variables are measured in Pakistani Rupee (PKR). For variable definitions, see Appendix Table 2.

\begin{tabular}{|c|c|c|c|c|c|c|c|c|c|c|c|c|}
\hline & \multicolumn{3}{|c|}{ All } & \multicolumn{3}{|c|}{ High } & \multicolumn{3}{|c|}{ Intermediate } & \multicolumn{3}{|c|}{ Low } \\
\hline & Mean & Median & St dev & Mean & Median & St dev & Mean & Median & St dev & Mean & Median & St dev \\
\hline \multicolumn{13}{|l|}{ Loan characte ris tics } \\
\hline Loan size & 1,920 & 62 & 15,942 & 2,060 & 50 & 19,076 & 2,730 & 72 & 22,320 & 1,390 & 66 & 68,812 \\
\hline Maturity & 761 & 365 & 992 & 722 & 365 & 1,055 & 726 & 364 & 1,098 & 807 & 375 & 880 \\
\hline Secured & 0.950 & 1.000 & 0.217 & 0.947 & 1.000 & 0.224 & 0.927 & 1.000 & 0.259 & 0.965 & 1.000 & 0.184 \\
\hline Non performing loans & 0.078 & 0 & 0.269 & 0.068 & 0.137 & 0.251 & 0.137 & 0.137 & 0.344 & 0.055 & 0.137 & 0.228 \\
\hline \multicolumn{13}{|l|}{ Bank characteristics } \\
\hline Capital ratio & 13.311 & 12.360 & 4.501 & 15.391 & 13.390 & 4.957 & 13.792 & 10.580 & 4.247 & 11.575 & 10.980 & 3.482 \\
\hline Total assets & 33,129 & 31,478 & 23,254 & 42,412 & 34,320 & 2,242 & 47,868 & 54,682 & 27,314 & 18,780 & 17,286 & 89,040 \\
\hline Liquid assets & 5,240 & 3,560 & 4,325 & 5,990 & 6,020 & 2,980 & 9,460 & 9,800 & 5,583 & 2,490 & 2,120 & 1,366 \\
\hline Number of branches & 620 & 272 & 536 & 946 & 994 & 544 & 880 & 1,078 & 482 & 252 & 122 & 250 \\
\hline \multicolumn{13}{|l|}{ Bank types (\%) } \\
\hline Nationalized Banks & 0.105 & & 0.307 & 0.137 & & 0.137 & 0.435 & & 0.496 & 0.007 & & 0.086 \\
\hline Private & 0.379 & & 0.485 & 0.117 & & 0.322 & 0.286 & & 0.452 & 0.616 & & 0.487 \\
\hline Privatized & 0.384 & & 0.486 & 0.739 & & 0.439 & 0.279 & & 0.449 & 0.185 & & 0.388 \\
\hline Islamic & 0.052 & & 0.222 & 0.024 & & 0.154 & 0.030 & & 0.170 & 0.083 & & 0.276 \\
\hline Foreign & 0.089 & & 0.285 & 0.144 & & 0.351 & 0.137 & & 0.137 & 0.097 & & 0.296 \\
\hline \multicolumn{13}{|l|}{ Loan types (\%) } \\
\hline Agriculture & 0.014 & & 0.118 & 0.022 & & 0.146 & 0.020 & & 0.140 & 0.006 & & 0.074 \\
\hline Consumer loans & 0.001 & & 0.038 & - & & - & 0.001 & & 0.030 & 0.003 & & 0.052 \\
\hline Export loans & 0.287 & & 0.453 & 0.296 & & 0.456 & 0.247 & & 0.431 & 0.303 & & 0.460 \\
\hline Financing & 0.075 & & 0.263 & 0.067 & & 0.251 & 0.151 & & 0.358 & 0.040 & & 0.196 \\
\hline Islamic & 0.052 & & 0.222 & 0.024 & & 0.154 & 0.030 & & 0.170 & 0.083 & & 0.276 \\
\hline Import loans & 0.002 & & 0.045 & 0.000 & & 0.010 & 0.002 & & 0.039 & 0.004 & & 0.061 \\
\hline Leasing & 0.087 & & 0.282 & 0.137 & & 0.137 & 0.137 & & 0.137 & 0.137 & & 0.137 \\
\hline Micro credit & 0.002 & & 0.050 & 0.030 & & 0.172 & 0.017 & & 0.128 & 0.164 & & 0.370 \\
\hline Overdraft & 0.447 & & 0.497 & 0.005 & & 0.071 & 0.001 & & 0.025 & 0.002 & & 0.039 \\
\hline Term loan & 0.032 & & 0.175 & 0.550 & & 0.498 & 0.485 & & 0.500 & 0.355 & & 0.479 \\
\hline Number of observations & 33,245 & & & 10,603 & & & 7,786 & & & 14,856 & & \\
\hline
\end{tabular}


Table 3

\section{Bank lending channe I: Intensive margin}

This table presents the fixed effects regression results of the impact of financial shock on low and intermediate exposure banks during the GFC. All regressions include firm fixed effects, regressions 2 to 4 include loan type dummies and bank controls and regressions 3 and 4 include macroeconomic variables. Standard errors are clustered at firm level. For definitions of the variables, see Appendix Table 2. For each independent variable, the top row reports the estimated coefficient, and the bottom row reports the t-statistic in parentheses. * Indicates significance at the $10 \%$ level, ** Indicates significance at the $5 \%$ level and $* * *$ Indicates significance at the $1 \%$ level.

\begin{tabular}{lcccc}
\hline & \multicolumn{4}{c}{ Log change in bank lending } \\
\cline { 2 - 5 } & $\mathrm{FE}$ & $\mathrm{FE}$ & $\mathrm{FE}$ & $\mathrm{FE}$ \\
\cline { 2 - 5 } & $(1)$ & $(2)$ & $(3)$ & $(4)$ \\
\hline Intermediate Exposure & $1.89^{* * *}$ & $3.76 * * *$ & $1.36 * * *$ & $1.39^{* * *}$ \\
Low Exposure & $(3.13)$ & $(14.49)$ & $(4.40)$ & $(5.14)$ \\
& $2.43^{* * *}$ & $2.82^{* * *}$ & $0.97 * * *$ & $0.99 * * *$ \\
& $(7.18)$ & $(11.37)$ & $(4.25)$ & $(4.44)$
\end{tabular}

\section{Bank characteristics}

Capital ratio

Ln(Assets)

Liquid assets to total assets ratio

$\operatorname{Ln}$ (number of branches)

$\begin{array}{ccc}0.38 * * * & 0.14 * * * & 0.15 * * * \\ (9.43) & (6.01) & (6.22) \\ 0.98 & 0.74 * & 0.76 * \\ (1.32) & (1.87) & (1.75) \\ -56.57 * * * & -19.91 * * * & -18.76 * * * \\ -11.73) & (-11.88) & (-11.76) \\ -0.77 * * & -0.73 * * * & -0.80 * * * \\ (-1.97) & (-2.99) & (-3.04)\end{array}$

\section{Borrower/loan characteristics}

$\operatorname{Ln}$ (maturity)

$\begin{array}{ccc}-0.30 & 0.27 & 0.21 \\ (-1.08) & (1.21) & (0.98) \\ 0.39 & -0.51 & -0.76 * * \\ (0.99) & (-1.64) & (-2.44) \\ 0.44 * * * & 0.52 * * * & 0.52 * * * \\ (5.72) & (6.60) & (6.55) \\ 3.10 * * * & 4.08 * * * & 3.86 * * * \\ (6.45) & (6.61) & (6.64)\end{array}$

\section{Macroeconomic variables}

GDP growth

$\begin{array}{cc}-4.87 \text { *** } & -4.80 \text { *** } \\ (-46.49) & (-41.02) \\ -65.30 * * * & -64.73 * * * \\ (-53.33) & (-53.46)\end{array}$

Firm fixed effects

Loan type dummies

Y

N

Bank controls

$\mathrm{N}$

$$
\begin{aligned}
& \mathrm{Y} \\
& \mathrm{Y} \\
& \mathrm{Y}
\end{aligned}
$$

$\mathrm{Y}$
$\mathrm{N}$
$\mathrm{Y}$

$\mathrm{Y}$

\section{$\mathrm{R}^{2}$




\section{Table 4}

\section{Bank lending channel for "foreign" banks}

This table presents the fixed effects regression results on the bank lending channel for "foreign" banks. All regressions include firm fixed effects, regressions 2 and 4 include loan type dummies, bank controls and macroeconomic variables. Standard errors are clustered at firm level. For definitions of the variables, see Appendix Table 2. For each independent variable, the top row reports the estimated coefficient, and the bottom row reports the tstatistic in parentheses. * Indicates significance at the $10 \%$ level, ** Indicates significance at the $5 \%$ level and $* * *$ Indicates significance at the $1 \%$ level.

\begin{tabular}{lcccc}
\hline & \multicolumn{4}{c}{ Log change in bank lending } \\
\cline { 2 - 5 } & $\mathrm{FE}$ & $\mathrm{FE}$ & $\mathrm{FE}$ & $\mathrm{FE}$ \\
\cline { 2 - 5 } & $(1)$ & $(2)$ & $(3)$ & $(4)$ \\
\hline Foreign & $-7.24^{* * *}$ & $-11.96^{* * *}$ & $-2.61 * *$ & $-2.64 * * *$ \\
& $(-8.89)$ & $(-5.27)$ & $(-2.47)$ & $(-2.63)$
\end{tabular}

Bank characteristics

Capital ratio

Ln(Assets)

Liquid assets to total assets ratio

Ln(number of branches)

$\begin{array}{ccc}0.26 * * * & 0.10 * * * & 0.11 * * * \\ (7.93) & (5.97) & (6.03) \\ 2.86 * * & 1.21 * * & 1.23 * * \\ (2.20) & (2.16) & (2.08) \\ -47.35 * * * & -16.49 * * * & -15.23 * * * \\ -11.22) & (-8.79) & (-9.18) \\ -2.13 * * * & -1.10 * * * & -1.16 * * * \\ (-2.84) & (-3.31) & (-3.35)\end{array}$

Borrowe r/loan characte ris tics

Ln(maturity)

$-0.29$

0.28

0.20

$(-1.22)$

$-0.02$

(1.34)

(0.99)

Secured

$(-0.04)$

$0.45 * * *$

$-0.63 * *$

$-0.90 * * *$

Ln(loan size $)$

(5.74)

$3.02 * * *$

$(-2.11)$

$0.52 * * *$

$(-2.98)$

$0.52 * * *$

(6.62)

(6.58)

$4.08 * * *$

$3.85 * * *$

(5.13)

(7.17)

(7.07)

Macroeconomic variables

GDP growth

$$
\begin{array}{cc}
-4.90 * * * & -4.83 * * * \\
(-41.01) & (-37.93) \\
-65.04 * * * & -64.42 * * * \\
(-49.36) & (-49.19)
\end{array}
$$

Ln(Trade deficit)

Firm fixed effects

Loan type dummies

Bank controls

$\begin{array}{cc}\mathrm{Y} & \mathrm{Y} \\ \mathrm{N} & \mathrm{N} \\ \mathrm{N} & \mathrm{Y}\end{array}$

$\mathrm{Y}$
$\mathrm{N}$
$\mathrm{Y}$

$\mathrm{Y}$
$\mathrm{Y}$
$\mathrm{Y}$

\begin{tabular}{lrrrr}
$\mathrm{R}^{2}$ & 0.003 & 0.103 & 0.348 & 0.350 \\
Number of observations & 33,245 & 33,245 & 33,245 & 33,245 \\
\hline
\end{tabular}


Table 6

Bank lending channel: Extensive margin

This table presents the fixed effects, Probit and OLS regression results on the extensive margin of bank lending channel when we consider small firms. All regressions include firm fixed effects except regressions 3, 4, 7 and 8, loan type dummies, bank controls and macroeconomic variables. Standard errors are clustered at firm level. For definitions of the variables, see Appendix Table 2. For each independent variable, the top row reports the estimated coefficient, and the bottom row reports the t-statistic in parentheses. * Indicates significance at the $10 \%$ level, ** Indicates significance at the $5 \%$ level and $* * *$ Indicates significance at the $1 \%$ level.

\begin{tabular}{lcccc}
\hline & \multicolumn{4}{c}{ Exit } \\
\cline { 2 - 5 } & FE & FE & Probit & OLS \\
\cline { 2 - 5 } & $(1)$ & $(2)$ & $(3)$ & $(4)$ \\
\hline Relatively low & $-0.05 * * *$ & $-0.03 * * *$ & $-0.05 * *$ & $-0.02 * * *$ \\
& $(-5.26)$ & $(-3.61)$ & $(-2.03)$ & $(-4.13)$ \\
Small firms & & $0.28 * * *$ & $0.97 * * *$ & $0.33 * * *$ \\
& & $(25.82)$ & $(33.27)$ & $(49.25)$ \\
Small firms*Relatively low & & $-0.02 *$ & -0.02 & -0.01 \\
& & $(-1.86)$ & $(-0.58)$ & $(-1.45)$
\end{tabular}

\begin{tabular}{cccc}
\multicolumn{4}{c}{ Entry } \\
\hline FE & FE & Probit & OLS \\
\hline$(5)$ & $(6)$ & $(7)$ & $(8)$ \\
\hline 0.01 & 0.01 & $0.10 * * *$ & $0.01 * * *$ \\
$(1.60)$ & $(1.61)$ & $(2.61)$ & $(3.74)$ \\
& $-0.03 * * *$ & $-0.15 * * *$ & $-0.03 * * *$ \\
& $(-4.43)$ & $(-3.22)$ & $(-8.11)$ \\
& 0.01 & 0.04 & 0.00 \\
& $(1.42)$ & $(0.80)$ & $(0.59)$
\end{tabular}

Bank characteristics

\begin{tabular}{|c|c|c|c|c|}
\hline Capital ratio & $\begin{array}{l}0.00 \text { *** } \\
(-2.84)\end{array}$ & $\begin{array}{l}0.00 \text { **** } \\
(-5.27)\end{array}$ & $\begin{array}{l}-0.01 * * * \\
(-3.64)\end{array}$ & $\begin{array}{l}0.00 \text { *** } \\
(-9.27)\end{array}$ \\
\hline Ln(Assets) & $\begin{array}{l}-0.06 \text { *** } \\
(-8.12)\end{array}$ & $\begin{array}{l}-0.06 \text { *** } \\
(-7.02)\end{array}$ & $\begin{array}{l}-0.16 \text { *** } \\
(-6.57)\end{array}$ & $\begin{array}{l}-0.07 \text { *** } \\
(-13.07)\end{array}$ \\
\hline Liquid assets to total assets ratio & $\begin{array}{l}0.14 \text { ** } \\
(2.32)\end{array}$ & $\begin{array}{l}0.20 \text { *** } \\
(2.76)\end{array}$ & $\begin{array}{c}-0.05 \\
(-0.25)\end{array}$ & $\begin{array}{l}0.11 \text { ** } \\
(2.44)\end{array}$ \\
\hline Ln(number of branches) & $\begin{array}{l}0.05 \text { *** } \\
(6.94)\end{array}$ & $\begin{array}{l}0.04 * * * \\
(6.51)\end{array}$ & $\begin{array}{l}0.14 \text { *** } \\
(7.74)\end{array}$ & $\begin{array}{l}0.05 \text { *** } \\
(11.97)\end{array}$ \\
\hline Borrower/loan characteristics & & & & \\
\hline Ln(maturity) & $\begin{array}{l}-0.03 \text { *** } \\
(-3.30)\end{array}$ & $\begin{array}{l}-0.03 \text { *** } \\
(-11.20)\end{array}$ & $\begin{array}{l}-0.13^{* * *} \\
(-17.11)\end{array}$ & $\begin{array}{l}-0.04 \text { *** } \\
(-23.05)\end{array}$ \\
\hline Secured & $\begin{array}{r}0.01 \\
(0.61)\end{array}$ & $\begin{array}{r}0.00 \\
(0.28)\end{array}$ & $\begin{array}{r}0.01 \\
(0.15)\end{array}$ & $\begin{array}{c}-0.01 \\
(-0.62)\end{array}$ \\
\hline Ln(loan size $)$ & $\begin{array}{l}-0.01 * * * \\
(-3.72)\end{array}$ & $\begin{array}{r}0.00 \\
(0.55)\end{array}$ & $\begin{array}{r}0.00 \\
(0.28)\end{array}$ & $\begin{array}{l}0.00 * * * \\
(3.33)\end{array}$ \\
\hline Non performing loan & $\begin{array}{l}-0.10 * * * \\
(-3.14)\end{array}$ & $\begin{array}{l}-0.10 * * * \\
(-6.40)\end{array}$ & $\begin{array}{l}-0.19 * * * \\
(-6.73)\end{array}$ & $\begin{array}{l}-0.08 \text { *** } \\
(-12.75)\end{array}$ \\
\hline
\end{tabular}

$\begin{array}{cccc}0.00 * * * & 0.00 * * * & 0.02 * * * & 0.00 * * * \\ (3.31) & (4.71) & (7.43) & (9.05) \\ 0.04 & 0.04 * * * & 0.27 * * * & 0.05 * * * \\ (1.39) & (6.14) & (7.19) & (15.11) \\ -0.44 * * * & -0.45 * * * & -3.82 * * * & -0.56 * * * \\ (-10.27) & (-9.67) & (-12.96) & (-19.63) \\ -0.03 & -0.03 * * * & -0.21 * * * & -0.04 * * * \\ (-1.58) & (-6.33) & (-7.63) & (-14.57)\end{array}$

\section{Macroeconomic variables}

GDP growth

$0.11 * * * \quad 0.10 * * * \quad 0.54 * * * \quad 0.12 * * *$ $(14.04) \quad(44.45) \quad$ (48.85) $\quad$ (84.03)

Ln(Manufacturing production)

$\begin{array}{cccc}1.16 \text { *** } & 1.10 \text { *** } & 5.45 \text { *** } & 1.28 \text { *** } \\ 12.89) & (18.01) & (28.60) & (33.37)\end{array}$

\begin{tabular}{|c|c|c|c|}
\hline $0.04 * * *$ & $0.04 * * *$ & $0.21 * * *$ & $0.04 * * *$ \\
\hline$(5.58)$ & (18.62) & (16.94) & $(35.83)$ \\
\hline-0.01 & -0.01 & -0.07 & 0.00 \\
\hline$(-0.98)$ & $(-1.15)$ & $(-1.20)$ & $(0.43)$ \\
\hline$-0.01 * * *$ & $-0.01 * * *$ & $-0.05 * * *$ & $-0.01 * * *$ \\
\hline$(-28.27)$ & $(-31.39)$ & $(-33.09)$ & $(-53.62)$ \\
\hline $0.20 * * *$ & $0.20 * * *$ & $0.54 * * *$ & $0.13 * * *$ \\
\hline (6.65) & (19.26) & (13.87) & $(31.25)$ \\
\hline
\end{tabular}

\begin{tabular}{|c|c|c|c|}
\hline$-0.19 * * *$ & $-0.19 * * *$ & $-0.93 * * *$ & $-0.19 * * *$ \\
\hline$(-118.94)$ & $(-123.55)$ & $(-66.67)$ & $(-206.39)$ \\
\hline$-2.07 * * *$ & $-2.06 * * *$ & $-13.1 * * *$ & $-2.16 * * *$ \\
\hline$(-25.40)$ & $(-51.36)$ & $(-45.55)$ & $(-89.87)$ \\
\hline
\end{tabular}

Firm fixed effects

Loan type dummies

Bank controls

$\begin{array}{lll}\mathrm{Y} & \mathrm{Y} & \mathrm{N} \\ \mathrm{Y} & \mathrm{Y} & \mathrm{Y} \\ \mathrm{Y} & \mathrm{Y} & \mathrm{Y}\end{array}$

$\begin{array}{ll}\mathrm{N} & \mathrm{N} \\ \mathrm{Y} & \mathrm{Y} \\ \mathrm{Y} & \mathrm{Y}\end{array}$

$\mathrm{R}^{2} /$ Pseudo $\mathrm{R}^{2}$
Number of observations

\begin{tabular}{rrrr}
0.129 & 0.178 & 0.179 & 0.219 \\
33,245 & 33,245 & 33,245 & 59,183 \\
\hline
\end{tabular}

\section{Table 5}

\section{Bank lending channel: Extensive margin}

This table presents the fixed effects and Probit regression results on the extensive margin of bank lending channel. All regressions include firm fixed effects except regressions 2 and 4, loan type dummies, bank controls and macroeconomic varaibles. Standard errors are clustered at firm level. For definitions of the variables, see Appendix Table 2. For each independent variable, the top row reports the estimated coefficient, and the bottom row reports the t-statistic in parentheses. * Indicates significance at the $10 \%$ level, $* *$ Indicates significance at the $5 \%$ level and $* * *$ Indicates significance at the $1 \%$ level. 
Table 7

Bank lending channel for small firms

This table presents the fixed effects and OLS regression results on the bank lending channel for small firms. All regressions include firm fixed effects except regression 4, loan type dummies, bank controls and macroeconomic variables. Standard errors are clustered at firm level. For definitions of the variables, see Appendix Table 2. For each independent variable, the top row reports the estimated coefficient, and the bottom row reports the t-statistic in parentheses.* Indicates significance at the $10 \%$ level, ** Indicates significance at the $5 \%$ level and $* * *$ Indicates significance at the $1 \%$ level.

\begin{tabular}{lcccc}
\hline & \multicolumn{4}{c}{ Log change in bank lending } \\
\cline { 2 - 5 } & FE & FE & FE & OLS \\
\cline { 2 - 5 } & $(1)$ & $(2)$ & $(3)$ & \multicolumn{1}{c}{$(4)$} \\
\hline Relatively low & $1.17 * * *$ & $1.15 * * *$ & $1.32 * * *$ & $1.21 * * *$ \\
& $(5.35)$ & $(6.23)$ & $(5.95)$ & $(8.74)$ \\
Small firms & & $-0.74 * * *$ & -0.45 & $-1.53 * * *$ \\
& & $(-3.72)$ & $(-1.54)$ & $(-9.36)$ \\
Small firms*Relatively low & & & -0.45 & $-0.57 * * *$ \\
& & & $(-1.38)$ & $(-2.97)$
\end{tabular}

Bank characteristics

Capital ratio

$\begin{array}{cccc}0.15 * * * & 0.15 * * * & 0.15 * * * & 0.16 * * * \\ (6.64) & (7.60) & (7.61) & (13.17) \\ 0.80 * & 0.81 * * * & 0.83 * * * & 1.41 * * * \\ (1.83) & (3.51) & (3.60) & (10.19) \\ -17.79 * * * & -17.94 * * * & -17.87 * * * & -18.45 * * * \\ -11.03) & (-9.65) & (-9.61) & (-16.54) \\ -0.78 * * * & -0.76 * * * & -0.78 * * * & -1.03 * * * \\ (-2.88) & (-4.46) & (-4.55) & (-10.03)\end{array}$

Borrowe r/loan characte ris tics

Ln(maturity)

0.21

$0.21 * * *$

$0.20 * * *$

$0.59 * * *$

(0.96)

(2.68)

$-0.79 * *$

$-0.77 * *$

(2.63)

(13.06)

Secured

$(-2.53)$

$\operatorname{Ln}($ loan size $)$

$0.52 * * *$

$(-2.13)$

$-0.75 * *$

$-0.45 * *$

Non performing loan

(6.56)

$0.50 * * *$

$(-2.08)$

$(-2.13)$

$0.50 * * *$

$0.39 * * *$

(44.25)

(44.18)

(51.92)

$3.86 * * *$

$3.86 * * *$

$3.85 * * *$

$2.36 * * *$

(6.69)

(9.13)

(9.11)

(14.88)

\section{Macroe conomic variables}

GDP growth

$$
-4.80 * * * \quad-4.79 * * * \quad-4.79 * * * \quad-5.26 * * *
$$

$$
\text { (-41.02) }
$$

$(-77.72)$

$(-145.30)$

Ln(Manufacturing production)

$$
-64.8 * * *
$$

$-64.64 * * *$

$-64.65 * * *$

$-68.85 * * *$

$(-54.05)$

$(-40.29)$

$(-40.30)$

$(-72.56)$

Firm fixed effects

Loan type dummies

Bank controls

$\begin{array}{ll}\mathrm{Y} & \mathrm{Y} \\ \mathrm{Y} & \mathrm{Y} \\ \mathrm{Y} & \mathrm{Y}\end{array}$

$\begin{array}{ll}\mathrm{Y} & \mathrm{N} \\ \mathrm{Y} & \mathrm{Y} \\ \mathrm{Y} & \mathrm{Y}\end{array}$

$\mathrm{R}^{2}$
Number of observations

0.351

0.351

0.351

0.373

33,245

33,245

33,245

59,183 
Table 8

B ank lending channel for different types of banks

This table presents the fixed effects regression results on the bank lending channel for private and big banks. All regressions include firm fixed effects, loan type dummies, bank controls and macroeconomic variables. Standard errors are clustered at firm level. For definitions of the variables, see Appendix Table 2. For each independent variable, the top row reports the estimated coefficient, and the bottom row reports the t-statistic in parentheses. * Indicates significance at the $10 \%$ level, $* *$ Indicates significance at the 5\% level and *** Indicates significance at the $1 \%$ level.

\begin{tabular}{|c|c|c|c|c|}
\hline & \multicolumn{4}{|c|}{ Log change in bank lending } \\
\hline & FE & FE & FE & FE \\
\hline & (1) & (2) & (3) & (4) \\
\hline \multirow[t]{2}{*}{ Relatively low } & $0.95 * * *$ & $1.75 * * *$ & $0.77 * * *$ & -0.24 \\
\hline & $(5.81)$ & $(9.46)$ & (3.97) & $(-0.86)$ \\
\hline \multirow[t]{2}{*}{ Private banks } & $1.53 * * *$ & $4.45 * * *$ & & \\
\hline & $(4.81)$ & $(11.73)$ & & \\
\hline \multirow[t]{2}{*}{ Private banks*relatively low } & & $-3.52 * * *$ & & \\
\hline & & $(-8.81)$ & & \\
\hline \multirow[t]{2}{*}{ Big banks } & & & $-1.48 * * *$ & $-3.09 * * *$ \\
\hline & & & $(-3.69)$ & $(-5.91)$ \\
\hline \multirow[t]{2}{*}{ Big banks*relatively low } & & & & $1.98 * * *$ \\
\hline & & & & $(5.73)$ \\
\hline \multicolumn{5}{|l|}{ B ank characte ris tics } \\
\hline \multirow[t]{2}{*}{ Capital ratio } & $0.17 * * *$ & $0.20 * * *$ & $0.13 * * *$ & $0.15 * * *$ \\
\hline & $(6.70)$ & $(7.59)$ & $(5.80)$ & $(6.26)$ \\
\hline \multirow[t]{2}{*}{ Ln(Assets) } & $0.84 * *$ & $0.95 * *$ & 0.14 & -0.05 \\
\hline & $(2.26)$ & $(2.54)$ & $(0.26)$ & $(-0.09)$ \\
\hline \multirow[t]{2}{*}{ Liquid assets to total assets ratio } & $-15.69 * * *$ & $-20.63 * * *$ & $-19.25 * * *$ & $-22.82 * * *$ \\
\hline & $(-8.55)$ & $(-9.68)$ & $(-11.93)$ & $(-13.55)$ \\
\hline \multirow[t]{2}{*}{ Ln(number of branches) } & $-0.45 *$ & $-0.44 *$ & 0.06 & 0.37 \\
\hline & $(-1.68)$ & $(-1.65)$ & $(0.14)$ & $(0.78)$ \\
\hline \multicolumn{5}{|l|}{ Borrowe r/loan characte ris tics } \\
\hline \multirow[t]{2}{*}{ Ln(maturity) } & 0.22 & 0.21 & 0.21 & 0.23 \\
\hline & $(0.97)$ & $(0.91)$ & $(0.97)$ & $(1.00)$ \\
\hline \multirow[t]{2}{*}{ Secured } & $-0.83 * * *$ & $-0.84 * * *$ & $-0.93 * * *$ & $-0.86 * * *$ \\
\hline & $(-2.69)$ & $(-2.71)$ & $(-3.06)$ & $(-2.76)$ \\
\hline \multirow{2}{*}{ Ln(loan size $)$} & $0.52 * * *$ & $0.52 * * *$ & $0.52 * * *$ & $0.52 * * *$ \\
\hline & $(6.53)$ & $(6.48)$ & $(6.56)$ & $(6.57)$ \\
\hline \multirow[t]{2}{*}{ Non performing loan } & $3.79 * * *$ & $3.77 * * *$ & $3.77 * * *$ & $3.74 * * *$ \\
\hline & $(6.35)$ & $(6.34)$ & $(6.10)$ & $(5.84)$ \\
\hline \multicolumn{5}{|l|}{ Macroeconomic variables } \\
\hline \multirow[t]{2}{*}{ GDP growth } & $-4.79 * * *$ & $-4.75 * * *$ & $-4.78 * * *$ & $-4.73 * * *$ \\
\hline & $(-44.25)$ & $(-41.94)$ & $(-44.76)$ & $(-45.24)$ \\
\hline \multirow[t]{2}{*}{ Ln(Manufacturing production) } & $-65.04 * * *$ & $-65.58 * * *$ & $-64.48 * * *$ & $-64.08 * * *$ \\
\hline & $(-56.53)$ & $(-56.17)$ & $(-51.16)$ & $(-46.94)$ \\
\hline Firm fixed effects & $\mathrm{Y}$ & $\mathrm{Y}$ & $\mathrm{Y}$ & $\mathrm{Y}$ \\
\hline Loan type dummies & $\mathrm{Y}$ & $\mathrm{Y}$ & $\mathrm{Y}$ & $\mathrm{Y}$ \\
\hline Bank controls & $\mathrm{Y}$ & $\mathrm{Y}$ & $\mathrm{Y}$ & $\mathrm{Y}$ \\
\hline $\mathrm{R}^{2}$ & 0.352 & 0.353 & 0.351 & 0.352 \\
\hline Number of observations & 33,245 & 33,245 & 33,245 & 33,245 \\
\hline
\end{tabular}


Table 9

Bank lending channel for differe nt tvbes of loans

Table 10

Bank lending channel and information asymmetry

This table presents the fixed effects regression results on the dynamics of information on the bank lending channel. All regressions include firm fixed effects, loan type dummies, bank controls and macroeconomic variables. Standard errors are clustered at firm level. For definitions of the variables, see Appendix Table 2. For each independent variable, the top row reports the estimated coefficient, and the bottom row reports the t-statistic in parentheses. *

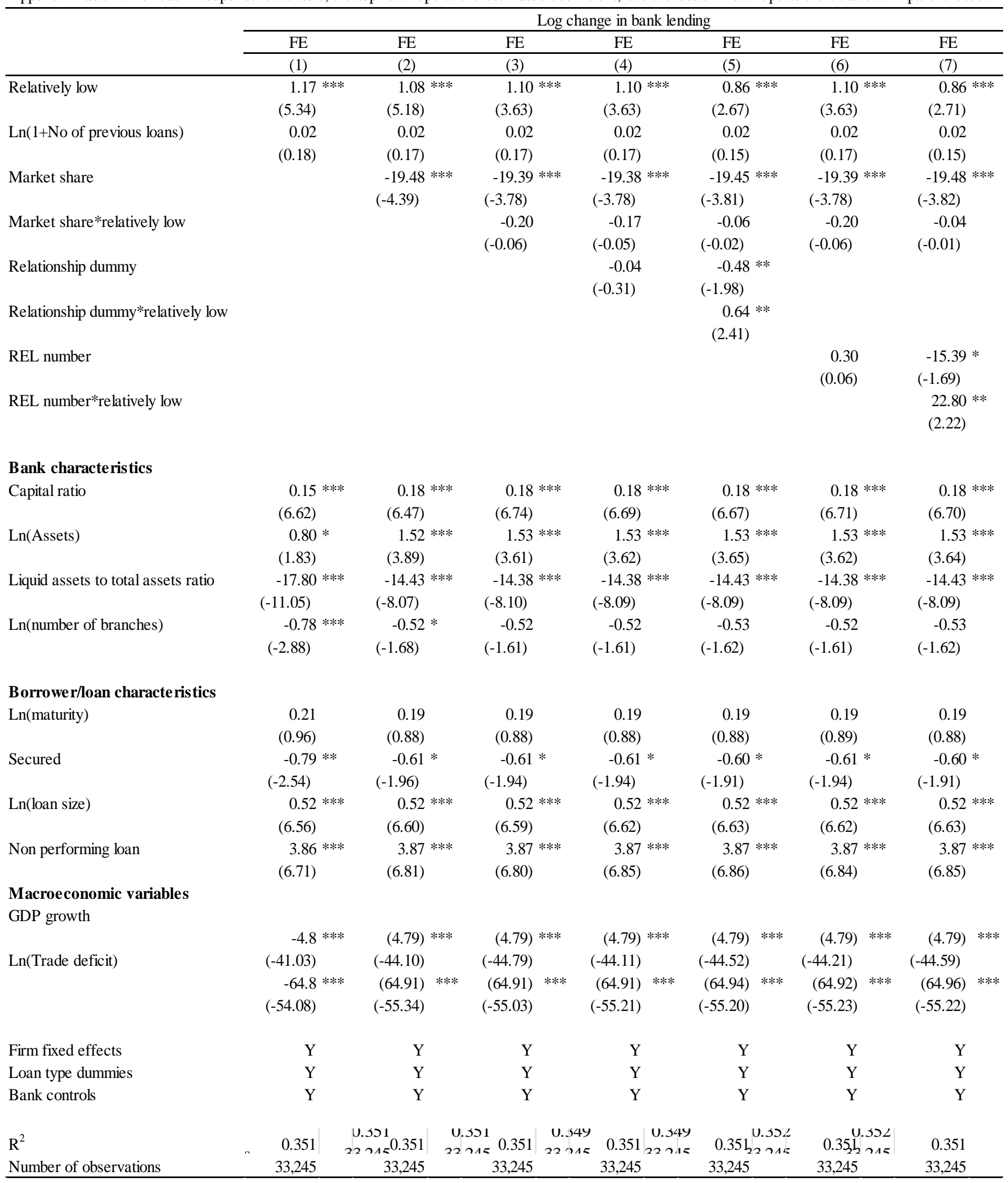




\section{Appendices:}

\section{Appendix Table 1}

\section{Trading partners of Pakistan}

This table provide the volume of trade with top twelve partners in the world for the period from 2006 to 2011.

\begin{tabular}{lrrrrrr}
\hline & \multicolumn{1}{c}{2006} & \multicolumn{1}{c}{2007} & \multicolumn{1}{c}{2008} & \multicolumn{1}{c}{2009} & \multicolumn{1}{c}{2010} & 2011 \\
\hline United States of America & $2,457,623$ & $1,245,627$ & $1,592,077$ & $1,420,631$ & $2,046,680$ & $2,085,948$ \\
China & $2,408,284$ & $3,550,471$ & $4,011,344$ & $2,781,915$ & $3,811,769$ & $4,791,694$ \\
United Arab Emirates & $2,166,537$ & 652,189 & $1,768,073$ & $1,811,002$ & $3,412,873$ & $4,897,792$ \\
Afghanistan & 926,559 & 748,185 & $1,362,075$ & $1,252,701$ & $1,546,291$ & $2,460,766$ \\
Germany & 492,740 & 401,416 & 585,628 & 551,895 & 4,372 & 311,664 \\
Spain & 378,858 & 374,992 & 354,304 & 292,044 & 339,721 & 386,373 \\
Bangladesh & 210,949 & 216,917 & 336,385 & 291,263 & 562,908 & 864,494 \\
Turkey & 199,700 & 286,457 & 334,867 & 254,967 & 488,415 & 595,803 \\
United Kingdom & 193,614 & 273,853 & 132,923 & 161,359 & 478,298 & 676,944 \\
Netherlands & 171,002 & 147,637 & 255,460 & 40,733 & 62,098 & 245,535 \\
Italy & 74,123 & 133,405 & 43,999 & 124,515 & 75,523 & 265,851 \\
Belgium & 44,666 & 154,244 & 169,996 & 141,852 & 269,856 & 382,946 \\
\hline
\end{tabular}


Appendix Table 2

Variable Definitions

\section{Dependent variable}

Lndifference (Lijb)

Independent variables

Lender Characteristics

High exposure banks

Intermediate exposure banks

Low exposure banks

Relatively low exposure banks

Exit

Entry

Islamic banks

Private banks

Privatized banks

\section{Bank Characteristics}

Capital ratio

Ln(Assets)

Liquid assets to total assets ratio

$\operatorname{Ln}$ (number of branches)

Borrower/Loan Characteristics

Ln(maturity)

Secured

Ln(loan size)

Non performing loan

Small firms

Export loans

Islamic loans

Agri loans

$\operatorname{Ln}(1+$ no of previous loans $)$

Market share

Relationship dummy

REL number

\section{Macroeconomic Variables}

GDP growth

Ln(Manufacturing production)

CPI

Unemployment rate

$\mathrm{Ln}$ (Trade deficit)

Interest rate

Ln(Broad money)
Difference between the natural logarithm value of pre crisis and post crisis loan amounts

Dummy variable equal to 1 for all banks that have over $8 \%$ of total borrowing outside Pakistan, 0 otherwise

Dummy variable equal to 1 for all banks that have between $4 \%$ to $8 \%$ of total borrowing ouside Pakistan, 0 otherwise

Dummy variable equal to 1 for all banks that have below $4 \%$ of total borrowing outside Pakistan, 0 otherwise

Dummy variable equal to 1 for all banks with international loans below $8 \%$ and 0 otherwise

Dummy variable equal to 1 if the loan is not renewed at some point during the Global Financial Crisis period of July 2007 to March 2009.

Dummy variable equal to 1 if a new loan is made after the Global Financial Crisis of July 2007 to March 2009.

Dummy variable equal to 1 for Islamic banks, 0 otherwise

Dummy variable equal to 1 for private banks 0 , otherwise

Dummy variable equal to 1 for banks that were previously government owned but were privatized during the financial liberalization era (hence privatized), 0 otherwise

Capital ratio of the bank

Natural logarithm of the total assets of the bank

Ratio of all liquid assets (assets which can easily be converted to cash) of the bank to total assets

Natural logarithm of the number of bank branches

Natural logarithm of the level of the maturity amount

Dummy variable equal to 1 if loan is secured and 0 otherwise

Natural logarithm of loan amount outstanding

Dummy variable equal to 1 if NPL amount exists, 0 otherwise

Dummy variable equal to 1 if firm is classified as small and 0 otherwise

Dummy variable equal to 1 if loan is export loan and 0 otherwise

Dummy variable equal to 1 if loan is Islamic loan and 0 otherwise

Dummy variable equal to 1 if loan is Agri loan and 0 otherwise

Natural logarithm of 1 plus the number of previous loans made to a borrower

Market share of deposit of a bank in percentage

Dummy variable equal to 1 if there is previous relationship with lender, 0 otherwise

Ratio of the number of loans advanced by a bank to a borrower and the total number of loans advanced by that bank

Gross Domestic Product growth

Natural logrithm of manufacturing production

Consumer Price Index

Unemployment rate

Natural logrithm of trade deficit

Interest rate

Natural logrithm of broad money (M2) 